\title{
The clinical effectiveness
}

\section{of cryopreserved human amniotic membrane in diabetic foot syndrome}

\author{
Ustymenko A. ${ }^{1,2}$, Nemtinov P., ${ }^{3,4}$, Bolgarska S. ${ }^{5}$, Zaika L..$^{5}$, Shablii V. ${ }^{4,6}$, Bukreieva T. ${ }^{4}$, Orlenko V. ${ }^{5}$, Palianytsia S. ${ }^{3}$ \\ ${ }^{1}$ State Institute of Genetic and Regenerative Medicine, National Academy of Medical Sciences of Ukraine, Kyiv, Ukraine \\ ${ }^{2} D$. F. Chebotarev State Institute of Gerontology, National Academy of Medical Sciences of Ukraine, Kyiv, Ukraine \\ ${ }^{3}$ Coordination Center for Transplantation of Organs, Tissues and Cells, Ministry of Health of Ukraine, Kyiv, Ukraine \\ ${ }^{4}$ Institute of Cell Therapy, Kyiv, Ukraine \\ ${ }^{5}$ V. P. Komisarenko State Institute of Endocrinology, National Academy of Medical Sciences of Ukraine, Kyiv, Ukraine \\ ${ }^{6}$ Institute of Molecular Biology and Genetics, National Academy of Sciences of Ukraine, Kyiv, Ukraine \\ Corresponding author’s e-mail: nemtinov@stemcellclinic.com
}

\section{ABSTRACT}

Diabetic foot syndrome with chronic non-healing ulcers is the most common complication and cause of limb amputation in diabetes. The search for effective therapeutic agents and their inclusion in treatment protocols is a priority due to the increase in the number of cases of this socially significant disease and disability among the working population every year.

THE PURPOSE of the study is to evaluate the safety and primary effectiveness of cryopreserved human amniotic membrane in the treatment of chronic non-healing ulcers in diabetic foot syndrome.

MATERIALS AND METHODS. The pilot clinical study described 4 clinical cases of patients with diabetes mellitus type I and II (1 woman and 3 men aged 52 to 68 years) with chronic non-healing leg ulcers under standard therapy. After previous wound bed preparation, the applications of the cryopreserved human amniotic membrane were performed. Once a week after the application, the dynamics of ulcers healing was assessed. Blood glucose levels were determined before amniotic membrane treatment and two hours after the procedure.

RESULTS. As results of weekly applications of cryopreserved human amniotic membrane there was a gradual decrease in the ulcer area from the initial size and increase the healing rate. Thus, at the second visit (after 7 days) the reduction in the ulcer area from the initial size in patient 1 was $33 \%$, patient $2-25 \%$, patient $3-33 \%$ and patient $4-3 \%$, and the healing rate $-4.7 \%, 3.6 \%, 4.7 \%$ and $0.43 \%$ per day, respectively. The use of human amniotic membrane did not affect blood glucose levels when comparing values before application and two hours after the procedure. Regular follow-up visits of patients 3, 6, 9 and 12 months after the start of the study showed no recurrence of ulcers.

CONCLUSION. It has been shown that the use of cryopreserved human amniotic membrane in patients with diabetes mellitus and diabetic foot syndrome with chronic ulcers results in complete healing of ulcers with stable remission during the year of observation.

KEY WORDS: diabetes; diabetic foot; cryopreserved human amniotic membrane; tissue therapy

Every year, the incidence of diabetes and mortality from its complications is growing worldwide, especially among working-age population. According to the World Health Organization, between 2000 and 2016, the number of deaths from diabetes and related complications increased by $5 \%$ in both high-income and low-income countries [1].

It is known that diabetic foot syndrome (DFS) is the most common symptom complex of anatomical and functional lesions in diabetes, in the development of which a significant role is played by peripheral neuropathy, angiopathy, osteoarthropathy, disorders of tissue metabolism. Diabetic angiopathy plays a major role in the pathogenesis of diabetic foot formation. In turn, sensory neuropathy - a decrease or loss of sensitivity (pain, tactile, proprioceptive, temperature) in diabetic neuropathy - leads to microtraumas that are not recognized in time, quickly become infected and necrotic ulcerated lesions occurs with the possible development of gangrene and to amputation of the legs [2]. According to Schofield et al., patients with diabetes not only have twice the risk of leg and foot amputations compared to patients without diabetes, but also have an increased risk of death - survival after 5 years was only $31.9 \%$ [3]. According to the Center for Public Health of the Ministry of Health of Ukraine, more than $70 \%$ of the total numbers of annual limb amputations are the result of diabetes [4].

Due to deregulation of the phases of normal ulcer healing in diabetes, the wound healing is very slow and delayed in the inflammatory 


\begin{tabular}{|c|c|c|}
\hline FACTOR & ACRONYM & FUNCTION \\
\hline Epidermal Growth Factor & EGF & \multirow{2}{*}{$\begin{array}{l}\text { Proteins that stimulate proliferation, differentiation of epithelial cells, promote the formation } \\
\text { of granulation tissue }[28,29,30] \text {. }\end{array}$} \\
\hline Hepatocyte Growth Factor & HGF & \\
\hline $\begin{array}{l}\text { Transforming Growth } \\
\text { Factor beta }\end{array}$ & TGF- $\beta$ & $\begin{array}{l}\text { Plays a crucial role in maintaining skin homeostasis. TGF- } \beta \text { signaling is important for } \\
\text { epithelialization, inflammation, angiogenesis, and granulation tissue formation during wound } \\
\text { healing [31]. }\end{array}$ \\
\hline $\begin{array}{l}\text { basic Fibroblast Growth } \\
\text { Factor }\end{array}$ & bFGF & \multirow{3}{*}{$\begin{array}{l}\text { Proteins that promote cell proliferation and extracellular matrix synthesis by resident skin } \\
\text { cells }[32,33] \text {. }\end{array}$} \\
\hline $\begin{array}{l}\text { Platelet-Derived Growth } \\
\text { Factor }\end{array}$ & PDGF & \\
\hline $\begin{array}{l}\text { Vascular Endothelial } \\
\text { Growth Factor }\end{array}$ & VEGF & \\
\hline $\begin{array}{l}\text { Keratynocite Growth } \\
\text { Factor }\end{array}$ & KGF & Growth factor required for keratinocyte proliferation and differentiation, wound epithelialization [34]. \\
\hline Nerve Growth Factor & NGF & Protein that supports the viability of neurons, stimulates their development and activity [35]. \\
\hline Placental Growth Factor & PIGF & Has a pronounced angiogenic potential; involved in cell differentiation, alternative splicing [36]. \\
\hline $\begin{array}{l}\text { Interleukin-1 Receptor } \\
\text { Antagonist }\end{array}$ & IL-1RA & $\begin{array}{l}\text { By binding to the interleukin-1 receptor, it inhibits the activation of the intracellular signaling } \\
\text { cascade of this proinflammatory cytokine [37]. }\end{array}$ \\
\hline $\begin{array}{l}\text { Growth-regulated } \\
\text { oncogene a }\end{array}$ & Groa/CXCL1 & $\begin{array}{l}\text { Chemokine, which acts as a chemoattractant for immune cells, including neutrophils and other } \\
\text { non-hematopoietic cells, to the site of injury or infection and plays an important role in the } \\
\text { regulation of immune and inflammatory responses [38]. }\end{array}$ \\
\hline $\begin{array}{l}\text { Inter-Cellular Adhesion } \\
\text { Molecule }\end{array}$ & SICAM & $\begin{array}{l}\text { Provides leukocyte-endothelial adhesion and transmigration during inflammation, which promotes } \\
\text { wound healing [39]. }\end{array}$ \\
\hline Interleukins 4, 6, 8, 10 & $\begin{array}{l}\text { IL-4, IL-6, } \\
\text { IL-8, IL-10 }\end{array}$ & $\begin{array}{l}\text { Influence the processes of keratinocyte and fibroblast proliferation, synthesis and degradation of } \\
\text { the extracellular matrix, fibroblast chemotaxis and regulation of the immune response in the wound } \\
{[40,41] \text {. }}\end{array}$ \\
\hline $\begin{array}{l}\text { Monocyte } \\
\text { Chemoattractant Protein-1 }\end{array}$ & MCP-1 & $\begin{array}{l}\text { One of the key chemokines that regulate the migration and infiltration of monocytes / macrophages } \\
\text { into the wound. Promotes angiogenesis and meets the metabolic needs of proliferating cells [42]. }\end{array}$ \\
\hline $\begin{array}{l}\text { Macrophage Migration } \\
\text { Inhibitory Factor }\end{array}$ & MIF & $\begin{array}{l}\text { Provides long-term activation of signaling pathways of cell proliferation; inhibits apoptosis of many } \\
\text { cell types by inhibiting p53 activity. Enhances the expression of TLR4 and, accordingly, provides an } \\
\text { adequate immune response to gram-negative bacteria. } \\
\text { Promotes the production of pro-inflammatory molecules: TNF, IFN- } \gamma \text {, IL-1 } \beta, \text { IL-2, IL-6, IL-8, NO, } \\
\text { COX2, prostaglandins. Affects cell migration by interacting with chemokine receptors CXCR2 and } \\
\text { CXCR4 }[43,44] \text {. }\end{array}$ \\
\hline $\begin{array}{l}\text { Plasminogen activator } \\
\text { inhibitor-1 }\end{array}$ & PAI-1 & $\begin{array}{l}\text { A key regulator of the tissue repair process. PAl-1 attenuates pericellular proteolysis by inhibiting } \\
\text { the catalytic activity of urokinase and tissue plasminogen activators (UPA and tPA) [45]. }\end{array}$ \\
\hline $\begin{array}{l}\text { Stromal cell-Derived } \\
\text { Factor }\end{array}$ & SDF-1a & $\begin{array}{l}\text { Accelerates the healing of skin wounds, promotes migration and proliferation of resident epidermal } \\
\text { stem cells [46]. }\end{array}$ \\
\hline $\begin{array}{l}\text { Granulocyte - Colony } \\
\text { Stimulating Factor }\end{array}$ & G-CSF & $\begin{array}{l}\text { Stimulates the growth and differentiation of hematopoietic cells, indirectly affects the strengthening } \\
\text { of the antimicrobial response, activates Th1-dependent immune response, angiogenesis [47]. }\end{array}$ \\
\hline
\end{tabular}

phase, as both the functional activity of neutrophils and macrophages and the expression of growth factors are reduced. Uncontrolled proteolysis is observed, which leads to an imbalance between the accumulation of extracellular matrix proteins and their degradation by proteases with tissue destruction in chronic ulcer [5].

There are three phases of normal wound healing: inflammatory, regeneration (granulation process) and proliferation (epithelialization, scar remodeling). The dynamic process of healing and transition from chronic to reparative requires a balanced interaction of growth factors that are present in a certain phase of normal wound healing: IL-10, IL-1ra and a2-macroglobulin in inflammatory phase; vascular endothelial growth factor (VEGF), platelet-derived growth factor (PDGF) and fibroblasts in proliferative phase; transforming growth factor beta (TGF- $\beta$ ), keratinocyte growth factor (KGF) and matrix metalloproteinases or tissue inhibitors of metalloproteinases (MMPs/TIMPs) in remodeling phase. But, as a result of the interaction of multiple, reinforcing each other, pathogenetic factors (peripheral angiopathy, neuropathy, microtrauma, infection), this balance is disturbed, resulting in an increased likelihood of diabetic foot infection with subsequent development of gangrene, sepsis, osteomyelitis. Even the use of modern treatments for DFS including hyperbaric oxygen therapy, collagen wound dressings, platelet-derived growth factors (PDGF), platelet-rich plasma (PRP), negative pressure wound therapy (NPWT) proves to be ineffective and the number of leg amputations does not decrease [6].

The goal of healing diabetic ulcers is to promote the transition from chronic to acute inflammation state, to balance the degradation and synthesis of collagen by fibroblasts to avoid fibrosis and conditions conducive to granulation and epithelialization. These processes are possible in the presence of a number of certain growth factors and stimulation of angiogenesis.

Thanks to modern advances in regenerative medicine, which offers a wide range of methodological approaches using cell and tissue technologies, it has become possible for stem cells application to heal wounds 
of various origins, including diabetes $[7,8]$. Significant interest in stem cells is due to their ability to self-repair, migrate to the site of damage and differentiate into certain cell types [9]. Their therapeutic potential is due to the ability to secrete proregenerative cytokines that are necessary for successful wound healing: TGF- $\beta$, VEGF, PDGF, fibroblast growth factor (FGF), hepatocyte growth factor (HGF), epidermal growth factor (EGF) [10]. There are many types of cells used to heal wounds and regenerate damaged skin in experiment, including embryonic stem cells (ESCs), induced pluripotent stem cells (iPSCs), and adult stem cells derived from various sources: bone marrow-derived mesenchymal stem cells (BM-MSCs), adipose-derived stem cells (ADSCs), umbilical cord-derived mesenchymal stem cells (UC-MSCs) [11]

However, it should be noted that embryonic pluripotent stem cells and induced pluripotent stem cells derived from the adult body, in addition to ethical limitations in some countries (in the case of ESCs), have methodological difficulties of their obtaining (inefficient reprogramming of cells using high-cost reagents) and the risk of malignancy due to the use of retroviral vectors (in the case of iPSCs). Therefore, they cannot be considered available and safe for cell therapy and require further analysis of safety and efficacy $[12,13,14]$.

Human extraembryonic organs, including the placenta and amniotic membrane, are of particular interest, as an easily accessible, safe source of stem cells with high proliferative and regenerative potential and the possibility of immediate use "on demand". From the placenta, at least four populations of stem cells or their precursors can be isolated, grown in vitro and preserved: human amniotic epithelial cells (hAECs), human amniotic mesenchymal stromal cells (hAMSCs), human chorionic mesenchymal stromal cells (hCMSCs) and human chorionic trophoblast cells (hCTCs) $[15,16,17]$. These cells have a higher potential for self-renewal and differentiation than multipotent mesenchymal stromal cells derived from other sources, including bone marrow or adipose tissue [18]. Therefore, they are successfully used for cell therapy in various diseases $[19,20]$.

Amniotic membrane (AM), due to its unique biological composition, has been used in medicine for over a century, especially in the field of ophthalmology and dermatology $[21,22,23,24]$. AM is an avascular, thin and very strong biological material rich in extracellular matrix proteins, which consists of an epithelial layer, a basement membrane, a compact layer, a fibroblast layer and an intermediate layer. Due to the unique cellular composition of each layer (containing neonatal fibroblasts, epithelial cells, mesenchymal stem cells, macrophages), the content of different types of collagen (I, III, IV, V), structural glycoproteins (fibronectin, laminins, nidogen) and proteoglycans (chondroitin sulfate and dermatan sulfate, hyaluronan, decorin, biglycan) ensures the structural and mechanical integrity of the membrane. And the presence in the AM of numerous signaling molecules, growth factors and cytokines that enhance angiogenesis and proliferation of dermal fibroblasts, inhibit the development of fibrosis, inflammation and scarring as well as promote tissue repair during implantation in chronic wounds, in fact, provide it with the properties of antimicrobial biological bandage (Table 1) [25, 26, 27, 80].

Due to the diverse cellular composition in the native state, as well as the preserved privileged immune status, $A M$ is of considerable interest for experimental research and clinical application. In addition, a significant advantage for the use of such material is the absence of any ethical and legal restrictions, as postnatal tissues (placenta, umbilical cord, umbilical cord blood) after birth are disposed of in the absence of informed consent of the mother to preserve them.

Since the native amniotic membrane has a short lifespan and risk of transmitting viral infections, scientists have developed a variety of techniques to preserve this product. Due to advanced biotechnologies and improved preservation protocols, AM is available in several versions: decellularized, lyophilized [48, 49, 50] and cryopreserved form [51, 52].

Lyophilization method is a preservation technique in which water is removed from the tissue by sublimation, which subsequently affects the biological and physical properties of the product: the content of active proteins, growth factors and membrane thickness decreases [54, 55]. It is an inexpensive method of preservation, as well as preservation of AM by a method of drying in a laminar flow air cabinet. Usually lyophilized membranes are sterilized by gamma irradiation, and the final product is stored at room temperature. At the same time, it is shown that the process of sterilization by gamma irradiation reduces the mechanical properties of AM [56].

Decellularization of AM is used to obtain techniques based on extracellular matrix [57]. The method aims to remove the main immunogenic cellular components, membrane antigens and soluble proteins, but leads to a significant reduction in the thickness of $A M$ and a slight decrease in tensile strength, elongation and elasticity [58].

Cryopreservation with cryoprotectants (glycerol, dimethyl sulfoxide) allows to preserve the maximum cellular composition, proteins and growth factors compared to the methods of preservation by lyophilization and drying [53]. The biggest disadvantage of the cryopreservation method is the need for expensive low-temperature equipment and compliance with the cold regime during transportation to the place of the request. Modern protocols for the storage of postnatal tissues in certain cryopreservation medium at low temperatures of liquid nitrogen can maintain high viability of tissues and cells after thawing, and, accordingly, make them suitable for immediate use $[59,60]$.

The PURPOSE of the study is to evaluate the safety and primary effectiveness of cryopreserved human amniotic membrane in the treatment of chronic non-healing leg ulcers in diabetic foot syndrome.

\section{MATERIALS AND METHODS}

The research was conducted on the basis of the State Institution "V. P. Komissarenko Institute of Endocrinology and Metabolism of the National Academy of Medical Sciences of Ukraine" in the clinical study "The efficacy of cryopreserved nuclear umbilical cord blood cells, cryopreserved multipotent mesenchymal stromal cells isolated from human placenta and cryopreserved human amniotic membrane separately and their combinations in diabetic peripheral neuropathy, peripheral arterial

Table 2. The main criteria for inclusion and non-inclusion of study participants.

\section{INCLUSION CRITERIA}

- Men and women aged 18 and older

- Diagnosed diabetes mellitus (type 1 or 2 )

- $\mathrm{HbA} 1 \mathrm{c}<12,0 \%$

- Unhealed ulcers that do not respond to standard treatment $\geq$ 4 weeks but not more than 12 months

- Skin ulcer on the foot or toes, size $\geq 1.0 \mathrm{~cm}^{2}-30.0 \mathrm{~cm}^{2}$

- No clinical signs of infection in the wound

- Adequate blood circulation in the affected foot

- Signed informed consent

\section{NON-ICLUSION CRITERIA}

- Age $\leq 18$ years

- Life expectancy is less than 12 months

- Participation in another clinical trial

- Any conditions that may impair or worsen wound healing

- Patients with reduced immunity (e.g. documented HIV infection, scleroderma, severe rheumatoid arthritis).

- Concomitant immunosuppressive therapy, including oral corticosteroids at a dose equivalent to $>5 \mathrm{mg}$ prednisolone per day

- The history of radiation therapy of the foot

- Pregnancy or lactation

- Cancer during the last 3 years with the exception of basal cell carcinoma and squamous cell carcinoma 
disease and trophic leg ulcers" (approved by the Academic Council of the Coordination Center for Organ, Tissue and Cell Transplantation, resolution № 6 , June 16, 2017). Patients who signed the "Informed Consent for Research" and met the inclusion criteria (Table 2) underwent a preliminary phase, namely: bacteriological assessment of ulcer debris and, if necessary, offloading interventions for the injured foot with half boot shoes.

Four patients with type I and II diabetes mellitus with diabetic polyneuropathy and angiopathy who had chronic foot ulcers with a minimum non-healing period of 6 months were selected to take part in the study (Table 3). All patients had impaired sensitivity up to the knee, such as: vibration, pain and tactile ones. Patients complained of pain in the affected leg when walking, fatigue. Under the conditions of standard therapy, tissue repair could not be achieved, so after a preliminary examination, it was decided to use the method of tissue therapy.

The study used a cryopreserved human amniotic membrane, which was thawed and applied to the wound, previously cleaned of necrotic tissue with a scalpel or debridement, once a week until complete healing.

\section{THE CRYOPRESERVED HUMAN AMNIOTIC MEMBRANE}

Amniotic membrane was obtained during a planned cesarean section at 38-40 weeks of gestation with informed consent to collect the mother's placenta and meet biosafety requirements [61]. The presence of hepatitis B surface antigen $(\mathrm{HbsAg})$, total antibodies against Threponema pallidum, hepatitis C, hepatitis B virus antigen, HIV-1/2 and cytomegalovirus was detected in the blood plasma of women by ELISA. Hepatitis $C$ and human immunodeficiency virus 1/2 RNA qualitative testing were determined by PCR. Prior to cryopreservation, amniotic membrane tissue fragments were tested for the absence of aerobic, anaerobic and fungal microflora by microbiological examination, as well as ELISA analysis for the absence of cytomegalovirus DNA, herpes simplex virus types 1 and 2, EpsteinBarr virus, Chlamydia trachomatis, Mycoplasma genitalium, Ureaplasma urealyticum Ureaplasma parvum.

AM under sterile conditions was separated from the placenta with forceps and transferred to a sterile dish, incubated for 40 minutes in Hanks' sterile solution (GE Healthcare Hyclone ${ }^{T M}$, Germany) with the addition of $2.5 \mu \mathrm{g} / \mathrm{mL}$ amphotericin (AppliChem, Germany), $100 \mathrm{IU} / \mathrm{mL}$ benzylpenicillin (Arterium, Ukraine), $50 \mu \mathrm{g} / \mathrm{mL}$ streptomycin (Arterium, Ukraine). The AM was then washed in separate sterile dishes containing Hanks' solution (GE Healthcare Hyclone ${ }^{T M}$, Germany), cut into $2 \times 2 \mathrm{~cm}$ fragments.

For cryopreservation, the fragmented tissue was transferred to 4.5 $\mathrm{mL}$ cryovials in cryopreservation medium consisting of Hanks' solution (GE Healthcare Hyclone ${ }^{T M}$, Germany) with $10 \%$ dimethyl sulfoxide (Sigma, USA). The material was stored and transported as required in liquid nitrogen in cryogenic Dewar tanks at a temperature $-196^{\circ} \mathrm{C}$.

The method of cryopreservation of tissue preparation developed and patented by the researchers of Institute of Cell Therapy provides high viability and functional activity of membrane cells after thawing $[59,62,63]$.

Cryopreserved amniotic membrane was thawed and washed from the cryopreservation media immediately before the use. To do this, cryovi-
Table 3. Characteristics of patients

\begin{tabular}{|c|c|c|c|c|}
\hline \# & $\begin{array}{c}\text { AGE, } \\
\text { YEARS }\end{array}$ & $\begin{array}{c}\text { DIABETES } \\
\text { MELLITUS, } \\
\text { TYPE }\end{array}$ & $\begin{array}{c}\text { DURATION } \\
\text { OF DIABETES, } \\
\text { YEARS }\end{array}$ & $\begin{array}{c}\text { THE PERIOD OF } \\
\text { NON-HEALING OF THE } \\
\text { WOUND AT THE TIME OF } \\
\text { TREATMENT, MONTHS }\end{array}$ \\
\hline 1 & 52 & $\|$ & 8 & 6 \\
\hline 2 & 62 & 1 & 23 & 11 \\
\hline 3 & 64 & $\|$ & 22 & 3 \\
\hline 4 & 68 & $\|$ & 8 & 7 \\
\hline
\end{tabular}

als with frozen amniotic membrane were removed from a Dewar tank with liquid nitrogen, kept at room temperature for about 15 seconds and thawed in a water bath heated to $+38-40^{\circ} \mathrm{C}$. The cryovial with amniotic membrane was thawed until the liquid phase followed by heating to room temperature. The tissue, washed from the cryoprotectant solution in Petri dishes in $0.9 \%$ saline, aseptically, was applied with tweezers directly to the wound, previously cleaned of necrotic masses, closed with a sterile Mesoft napkin (Paul Hartmann, Germany), and then fixed with a plaster (Molnlycke HC, Sweden) and Peha-Haft elastic bandage (Paul Hartmann, Germany). An offloading boot was put on the affected limb.

According to the study protocol, a regular visit of patients took place every 7 days, during which the level of glucose in the blood was determined (before the next application of amniotic membrane and 2 hours after application); the dimensions of the wound (height, width, depth) were visually and instrumentally measured using a ruler and wound area was calculated $\left(\mathrm{S}, \mathrm{cm}^{2}=\right.$ height $\mathrm{x}$ width). The percentage of ulcer area reduction (UAR) from the original size and the ulcers healing rate (UHR) were determined according to the formulas [89]:

$\operatorname{UAR}(\%)=\left(\left(\mathrm{S}_{0}-\mathrm{S}\right) / \mathrm{S}_{0}\right) \times 100 \%$, where $\mathrm{S}_{0}$ is the initial area at the beginning of treatment, $\mathrm{S}$ is the area of the ulcer at the time of measurement.

UHR $(\% /$ day $)=U A R / T$, where UAR is the percentage reduction in ulcer area, $\mathrm{T}$ - the number of days between measurements.

\section{RESULTS AND DISCUSSION}

All the patients had chronic non-healing ulcer at the start of the clinical trial, with a mean non-healing period of 6.6 months. It was shown that the participants of the study whose wounds were treated with cryopreserved amniotic membrane significantly accelerated the healing process. With weekly applications of AM, there was a gradual decrease in wound area (Table 4). After the second application, all patients had granulation tissue in the wound, a decrease in the area of the wound from the original size and increase the rate of healing.

Thus, at the time of the second visit (after 7 days) the percentage of UAR from the initial size of the ulcer on the foot in P1 was $33 \%$,

Table 4. The dynamics of the healing of foot ulcers during the application of AM.

\begin{tabular}{|c|c|c|c|c|c|c|c|c|c|c|c|c|c|c|c|c|c|}
\hline PATIENT & \multicolumn{2}{|c|}{$\begin{array}{c}\text { VISIT } \\
1\end{array}$} & \multicolumn{2}{|c|}{$\begin{array}{c}\text { VISIT } \\
2\end{array}$} & \multicolumn{2}{|c|}{$\begin{array}{c}\text { VISIT } \\
\mathbf{3}\end{array}$} & $\begin{array}{l}\text { VISIT } \\
4\end{array}$ & $\begin{array}{l}\text { VISIT } \\
5\end{array}$ & $\begin{array}{l}\text { VISIT } \\
6\end{array}$ & $\begin{array}{c}\text { VISIT } \\
7\end{array}$ & $\begin{array}{l}\text { VISIT } \\
8\end{array}$ & $\begin{array}{l}\text { VISIT } \\
9\end{array}$ & $\begin{array}{c}\text { VISIT } \\
10\end{array}$ & $\begin{array}{c}\text { VISIT } \\
11\end{array}$ & $\begin{array}{l}\text { VISIT } \\
12\end{array}$ & $\begin{array}{l}\text { VISIT } \\
13\end{array}$ & $\begin{array}{l}\text { VISIT } \\
14\end{array}$ \\
\hline \multicolumn{18}{|c|}{ Ulcer area, cm² $^{2}$} \\
\hline$\# 1$ & \multicolumn{2}{|c|}{1.8} & \multicolumn{2}{|c|}{1.2} & \multicolumn{2}{|c|}{0.4} & 0.2 & 0.15 & \multicolumn{9}{|c|}{ Complete healing } \\
\hline \#2 & \multicolumn{2}{|c|}{5.0} & \multicolumn{2}{|c|}{3.75} & \multicolumn{2}{|c|}{2.0} & 2.0 & 1.35 & 0.84 & 0.5 & \multicolumn{7}{|c|}{ Complete healing } \\
\hline \multirow{2}{*}{ \#3 } & S & $\mathrm{H}$ & S & $\mathrm{H}$ & S & $\mathrm{H}$ & \multirow{2}{*}{\multicolumn{11}{|c|}{ Complete healing }} \\
\hline & 3.0 & 1.5 & 2.0 & 1.5 & 0.15 & 0.35 & & & & & & & & & & & \\
\hline$\# 4$ & \multicolumn{2}{|c|}{9.9} & \multicolumn{2}{|c|}{9.6} & \multicolumn{2}{|c|}{6.25} & 5.0 & 4.0 & 3.6 & 2.25 & 2.25 & 2.25 & 1.0 & 1.0 & 1.0 & 0.5 & $\begin{array}{c}\text { Complete } \\
\text { healing }\end{array}$ \\
\hline
\end{tabular}



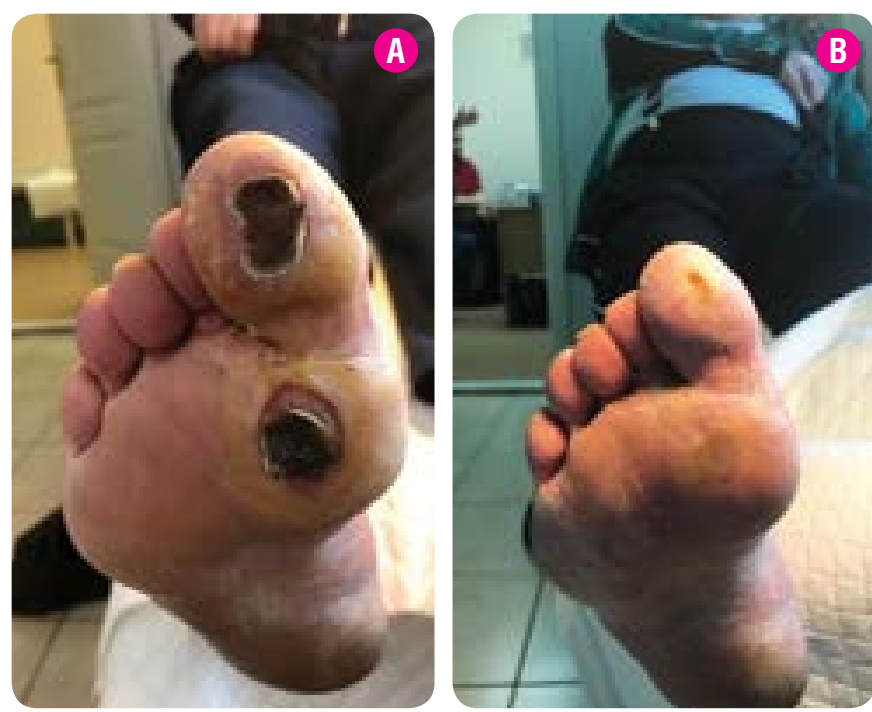

Fig. 1. Patient 3 (male, 64 years old) with diabetes mellitus and diabetic foot syndrome: $\mathbf{A}$ - ulcers before the application of AM; B - ulcers after the $3^{\text {rd }}$ application of AM. Photos provided with the patient's permission.

in $\mathrm{P} 2-25 \%$, in $\mathrm{P} 3-33 \%$ and in $\mathrm{P} 4-3 \%$, and $\mathrm{UHR}$ per day was $4.7 \%$, $3.6 \%, 4.7 \%$ and $0.43 \%$ in $\mathrm{P} 1, \mathrm{P} 2, \mathrm{P} 3$ and $\mathrm{P} 4$, respectively.

At the time of the last application UAR in comparison with the initial size in $\mathrm{P} 1$ was $92 \%$, for $\mathrm{P} 2-90 \%$, in P3 - $95 \%$ on the foot and $77 \%$ on the hallux (Fig. 1 A, B), in P4 - $95 \%$ Fig. 2 A, B). Last visits have shown complete wound healing in all patients.

The use of amniotic membrane did not affect blood glucose levels when comparing values before application and two hours after the procedure. Regular follow-up visits of patients 3, 6, 9 and 12 months after the start of the study showed no recurrence of ulcers.

According to the results of a pilot clinical study, in 4 patients after the use of cryopreserved amniotic membrane, the number of complications of diabetic ulcers associated with their infection decreased and, accordingly, the frequency of hospitalizations decreased. If in the treatment according to standard protocols (foot unloading, betadine dressings) the frequency of hospitalizations for each patient was at least twice a year, then after the application of amniotic membrane and ulcer healing for 12 months, no study participant had a relapse. In addition, no side effects have been reported with the use of allogeneic material.

Possible and infrequent side effects from the use of allogeneic AM may be: potential risk of infection, risk of prion infection [64] and individual hypersensitivity reaction $[87,88]$. Despite the widespread use of AM products, there are virtually no data on complications after its use [86].

The obtained results are quite consistent with those obtained in other clinical studies in which various preparations of amniotic membranes were used: Grafix [60], Epifix [65, 66, 67], Amnioband [68], AmnioExcel [69, 70], EpifixApligraf [67] Grafix NEOX Cord [71], dHACM [72, 73, 83]. According to the analysis of retrospective studies on the effectiveness of AM in the treatment of ulcers in DFS, most randomized clinical trials of tissue therapy were completed in a much shorter period of time compared to standard treatment groups. Chronic wounds that did not heal for a long time with standard treatment regimens were successfully regenerated under the influence of AM allografts. In addition, the frequency of recurrences after their healing decreased [81].

According to Glad $\mathrm{P}$ et al, the average healing time in the group of patients who received dehydrated amniotic membrane (DAM) with chronic non-healing wounds in DFS was 24 days $(95 \% \mathrm{Cl}, 18.9-29.2)$ versus 39 days $(95 \% \mathrm{Cl}, 36.4-41.9)$ for the group with the use of tissue-engineered skin substitutes (TESS). The proportion of healed wounds after the study
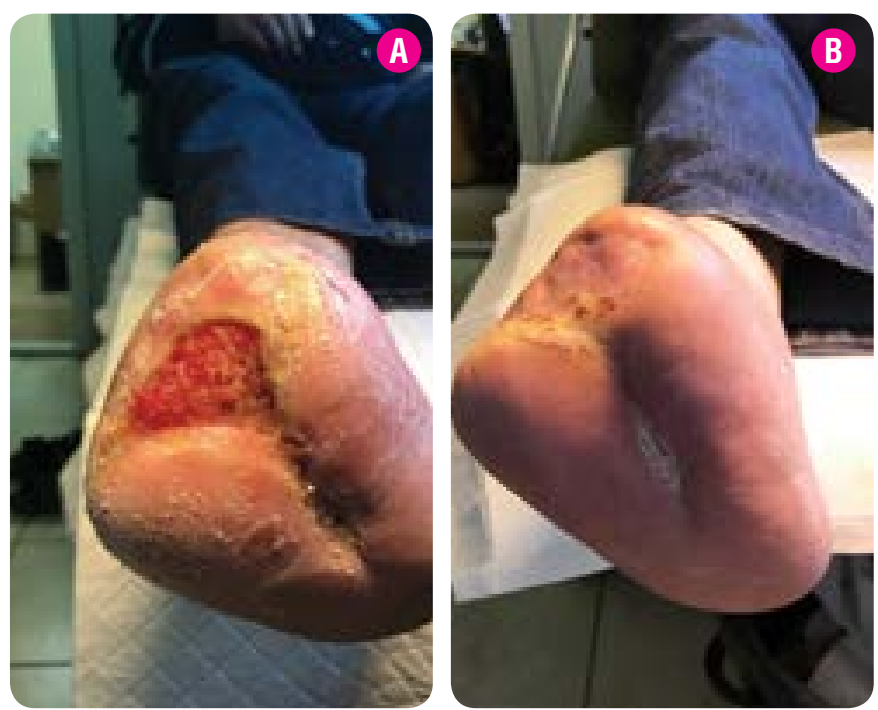

Fig. 2. Patient 4 (male, 62 years old) with diabetes mellitus and diabetic foot syndrome: $\mathbf{A}$ - ulcer before the application of $A M$; B - ulcer after the $13^{\text {th }}$ application of AM. Photos provided with the patient's permission.

(12 weeks) was $90 \%$ (27/30) for the group DAM versus $40 \%$ (12/30) for the group TESS. The average cost of the product for the group DAM was significantly lower than for the group TESS (DAM - US \$ 2,200; TESS USD $\$ 7,900)$. [84].

According to our observations, the longer the period of non-healing of the wound is, the more applications of human amniotic membrane had to be applied to diabetic foot ulcers (Table 4). Therefore, we believe that existing protocols for the treatment of chronic venous ulcers, critical limb ischemia associated with diabetes, and diabetic ulcer treatment protocols should be revised toward earlier use of cell and tissue therapies in combination with standard treatment protocols. This approach will significantly increase the efficiency and improve long-term treatment outcomes.

Our results can be explained by the fact that thawed living amnio-chorionic membrane provides delivery to the wound of numerous regulatory proteins, which include chemokines and cytokines, as well as angiogenic proteins [26, 74]. The influence of growth factors, in particular EGF, KGF, $\mathrm{HGF}, \mathrm{bFGF}, \mathrm{TGF}_{\beta}$ and extracellular matrix, produced by placental tissue cells has been shown to be crucial in wound healing and to achieve complete closure [9, 80, 81, 82].

Progressive techniques of cryopreservation of human amniotic membrane provide after thawing the preservation in the donor allogeneic AM of multipotent mesenchymal stromal cells capable to migrate into the wound after the application and activate resident patient stem cells, thereby enhancing wound healing. This property is especially important for the elderly, as with age there is a decrease in the number of MSCs and their dysfunction, which significantly inhibits the healing of wounds [83]

Thanks to advances in tissue treatment and preservation, more than 16 commercial extraembryonic products (AM, umbilical cord) are currently available in Europe and the United States for the treatment of chronic wounds in both cryopreserved and lyophilized form (Grafix Prime, Grafix Core, Neox, Clarix, Neox Cord, Clarix Cord, Amnio Graft, Amnio Guard, XWRAP, BioDFence, AmnioExcel, AmnioClear, EpiFix, Revitalon, ASGBarrie, Biovance [82]. Despite such progress, these products are not represented in the medical market of Ukraine due to their high cost. The price of such bandages per unit varies, depending on the size and manufacturer, from 1,500 to 10,000 US dollars [85]. Therefore, the development of domestic products from the human placenta is expedient and promising not only from medical but also economic point of view. 


\section{CONCLUSION}

\section{A pilot clinical trial demonstrated the efficacy and safety of cryopreserved human amniotic membrane applications in patients with diabetic foot syndrome and long-term non-healing ulcers, resulting in complete wound healing (average 8.3 weeks) and sustained remission, which was observed even a year after human amniotic membrane application.}

\section{REFERENCES:}

1. Available from: https://www.who.int/news-room/fact-sheets/detail/diabetes

2. Maren Volmer-Thole, Ralf Lobmann. Neuropathy and Diabetic Foot Syndrome. Int J Mol Sci. 2016; 17(6):917. https://doi.org/10.3390/ijms17060917

3. Schofield CJ, Libby G, Brennan G, MacAlpine R, Morris A, Leese GP. Mortality and Hospitalization in Patients After Amputation. Diabetes Care. 2006; 29:22522256. https://doi.org/10.2337/dc06-0926

4. Available from: https://www.phc.org.ua/news/ponad-70-zagalnoi-kilkosti-schorichnikh-amputaciy-e-naslidkom-cukrovogo-diabetu

5. Dehkordi AN, Babaheydari FM, Chehelgerdi M, Dehkordi ShR. Skin tissue engineering: wound healing based on stem-cell-based therapeutic strategies. Stem Cell Res Ther. 2019; 10. https://doi.org/10.1186/s13287-019-1212-2

6. Greer N, Foman NA, MacDonald R, et al. Advanced wound care therapies for nonhealing diabetic, venous, and arterial ulcers: a systematic review. Ann Intern Med. 2013; 159(8):532-542. https://doi.org/10. 7326/0003-4819-159-8-201310150-00006

7. Kosaric N, Kiwanuka H, Gurtne G. Stem Cell Therapies for Wound Healing. Expert Opin Biol Ther. 2019; Issue 6. https://doi.org/10.1080/14712598.2019.1596257

8. Garwood CS, Steinberg JS, Kim PJ. Bioengineered Alternative Tissues in Diabetic Wound Healing. Clin Podiatr Med Surg. 2015; 31(1):121-33. https://doi. org/10.1016/j.cpm.2014.09.004

9. Chen M, Przyborowski M, Berthiaume F. Stem cells for skin tissue engineering and wound healing. Crit Rev Biomed Eng. 2009; 37:399-421. https://doi.org/10.1615/ CritRevBiomedEng.v37.i4-5.50

10. Duscher D, Barrera J, Wong VW, Maan ZN, Whittam AJ, Januszyk M, et al. Stem cells in wound healing: the future of regenerative medicine? A mini-review. Gerontology. 2016; 62:216-25. https://doi.org/10.1159/000381877

11. Dash B, Xu Z, Lin L, Koo A, Ndon S, Berthiaume $F$, et al. Stem cells and engineered scaffolds for regenerative wound healing. Bioengineering. $2018 ; \mathbf{5}: 23$. https://doi.org/10.3390/bioengineering5010023

12. Guenou H, Nissan X, Larcher F, Feteira J, Lemaitre G, Saidani $M$, et al. Human embryonic stem-cell derivatives for full reconstruction of the pluristratified epidermis: a preclinical study. Lancet. 2009; 374:1745-53. https://doi.org/10.1016/S0140-6736(09)61496-3

13. Okano H,Nakamura M, Yoshida K, Okada Y, Tsuji O, Nori S, et al. Steps toward safe cell therapy using induced pluripotent stem cells. Circ Res. 2013; 112:523-33. https://doi.org/10.1161/CIRCRESAHA.111.256149

14. Okita K, Ichisaka T, Yamanaka S. Generation of germline-competent induced pluripotent stem cells. Nature. 2007; 448:313-7. https://doi.org/10.1038/nature05934

15. Parolini O, Alviano F, Bagnara GP, Bilic G, Bühring HJ, Evangelista $M$, et al. Concise review: isolation and characterization of cells from human term placenta: outcome of the first international Workshop on Placenta Derived Stem Cells. Stem Cells. 2008; 26:300-311. https://doi.org/10.1634/stemcells.2007-0594. https:// doi.org/10.1634/stemcells.2007-0594

16. Dua HS, Gomes JAP, King A. The amniotic membrane in ophthalmology. Survey of Ophthalmology. 2004; 49:51-77. https://doi.org/10.1016/j. survophthal.2003.10.004

17. Gomes JAP, dos Santos MS, Cunha MC, de Nadai Barros J, de Sousa LB. Amniotic membrane transplantation for partial and total limbal stem cell deficiency secondary to chemical burn. Ophthalmology. 2003; 11(3):466-473. https://doi.org/10.1016/S0161-6420(02)01888-2

18. Kern S, Eichler H, Stoeve J, Kluter H, Bieback K: Comparative analysis of mesenchymal stem cells from bone marrow, umbilical cord blood, or adipose tissue. Stem Cells. 2006; 24:1294-1301. https://doi.org/10.1634/stemcells.2005-0342. https://doi.org/10.1634/stemcells.2005-0342

19. de la Torre P, Pérez-Lorenzo MJ, Flores Al. Human placenta-derived mesenchymal stromal cells: a review from basic research to clinical applications. In: Valarmathi MT. editor. Stromal cells: structure, function, and therapeutic implications. London: IntechOpen, 2018. https://doi.org/10.5772/intechopen.76718

20. Macias MI, Grande J, MorenoA, Domínguez I, Bornstein R, Flores A. Isolation and characterization of true mesenchymal stem cells derived from human term decidua capable of multilineage differentiation into all 3 embryonic layers. Am J Obstet Gynecol 2010; 203:495.e9-23. https://doi.org/10.1016/j.ajog.2010.06.045

21. Davis JS. Skin grafting at the Johns Hopkins Hospital. Ann Surg. 1909; 50:542-549. https://doi.org/10.1097/00000658-190909000-00002

22. Dua HS, Gomes JA, King AJ, Maharajan V. The amniotic membrane in ophthalmology. Surv. Ophthalmol. 2004, 49:51-77. https://doi.org/10.1016/j. survophthal.2003.10.004

23. Portmann-Lanz CB, Schoeberlein A, Huber A, Sager R, Malek A, Holzgreve $W$, et al. Placental mesenchymal stem cells as potential autologous graft for pre- and perinatal neuroregeneration. Am J Obstet Gynecol. 2006; 194(3):664-73. https://doi.org/10.1016/j.ajog.2006.01.101

24. Abbasi-Kangevari M, Ghamari SH, Safaeinejad F, Bahrami S, Niknejad H. Potential Therapeutic Features of Human Amniotic Mesenchymal Stem Cells in Multiple Sclerosis: Immunomodulation, Inflammation Suppression, Angiogenesis Promotion, Oxidative Stress Inhibition, Neurogenesis Induction, MMPs Regulation, and Remyelination Stimulation. Front Immunol. 2019; 10:238. https://doi.org/10.3389/fimmu.2019.00238

25. Koob TJ, Lim JJ, Massee M, et al. Properties of dehydrated human amnion/chorion composite grafts: implications for wound repair and soft tissue regeneration. J Biomed Mater Res B Appl Biomater. 2014; 102:1353-1362. https://doi.org/10.1002/jbm.b.33141

26. Koob TJ, Rennert R, Zabek $N$, et al. Biological properties of dehydrated human amnion/chorion composite graft: implications for chronic wound healing. Int Wound J. 2013; 10:493-500. https://doi.org/10.1111/iwj.12140

27. Koob TJ, Lim JJ, Massee $M$, et al. Angiogenic properties of dehydrated human amnion/chorion allografts: therapeutic potential for soft tissue repair and regeneration. Vasc Cell. 2014; 6:10. https://doi.org/10.1186/2045-824X-6-10

28. Hardwicke J, Schmaljohann D, Boyce D, Thomas D. Epidermal growth factor therapy and wound healing - past, present and future perspectives. Surgeon. 2008; 6:172-7. https://doi.org/10.1016/S1479-666X(08)80114-X

29. Yoshida S, Yamaguchi Y, Itami S, Yoshikawa K, Tabata Y, Matsumoto K. Neutralization of Hepatocyte Growth Factor Leads to Retarded Cutaneous Wound Healing Associated with Decreased Neovascularization and Granulation Tissue Formation JID. 2003; 2:335-343. https://doi.org/10.1046/j.1523-1747.2003.12039.x

30. Nakamura T, Mizuno Sh. The discovery of Hepatocyte Growth Factor (HGF) and its significance for cell biology, life sciences and clinical medicine Proc Jpn Acad Ser B Phys Biol Sci. 2010; 86(6):588-610. https://doi.org/10.2183/pjab.86.588 
31. Ramirez H, Patel Sh, Pastar I. The Role of TGFß Signaling in Wound Epithelialization. Adv Wound Care (New Rochelle). 2014; 3(7):482-491. https://doi.org/10.1089/ wound.2013.0466

32. Abdelhakim M, Lin X, Ogawa R. The Japanese Experience with Basic Fibroblast Growth Factor in Cutaneous Wound Management and Scar Prevention: A Systematic Review of Clinical and Biological Aspects. Dermatol Ther. 2020; 10:569-587. https://doi.org/10.1007/s13555-020-00407-6

33. DiPietro LA, Polverini PJ. Role of the macrophage in the positive and negative regulation of wound neovascularisation. Am J Pathol. 1993; 143:678-684.

34. Bártolo I, Reis RL, Marques AP, Cerqueira MT. Keratinocyte Growth Factor-Based Strategies for Wound Re-Epithelialization. Tissue Engineering Part B. 2021. Available from: https://doi.org/10.1089/ten.teb.2021.0030

35. Aloe L, Rocco ML, Bianchi P, Manni L. Nerve growth factor: from the early discoveries to the potential clinical use. J Transl Med. 2012; 10:239. https://doi. org/10.1186/1479-5876-10-239

36. Cianfarani F, Zambruno G, Brogelli L, Sera F, Lacal PM, Pesce M, et al. Placenta Growth Factor in Diabetic Wound Healing. Am J Pathol. 2006; 169(4):1167-1182. https://doi.org/10.2353/ajpath.2006.051314

37. Tan LJ, Lash B, Karami R, Nayer B, Lu Y-Z, Piotto C, et al. Restoration of the healing microenvironment in diabetic wounds with matrix-binding IL-1 receptor antagonist. Commun Biol. 2021. Available from: http://www.nature.com/articles/s42003-021-01913-9 https://doi.org/10.1038/s42003-021-01913-9

38. Bodnar RJ. Chemokine Regulation of Angiogenesis During Wound Healing. 2015. Available from: https://doi.org/10.1089/wound.2014.0594

39. Witkowska AM, Borawska MH Soluble intercellular adhesion molecule-1 (sICAM-1): an overview. European Cytokine Network. 2004; 15(2):91-98.

40. Volpin G, Cohen M, Assaf M, Meir T, Katz R, Pollack S. Cytokine Levels (IL-4, IL-6, IL-8 and TGF $\beta$ ) as Potential Biomarkers of Systemic Inflammatory Response in Trauma Patients. Int Orthop. 2014; 38(6):1303-1309. https://doi.org/10.1007/s00264-013-2261-2

41. King A, Balaji S, Le L, Crombleholme T, Keswani S. Regenerative Wound Healing: The Role of Interleukin-10. 2014; 3(4):315-323. https://doi.org/10.1089/ wound.2013.0461

42. Ridiandries A, Tan JNM, Bursill C. The Role of Chemokines in Wound Healing. Int J Mol Sci. 2018; 19:3217. https://doi.org/10.3390/ijms19103217

43. Bloom J, Shan S, Al-Abed Y. MIF, a controversial cytokine: a review of structural features, challenges, and opportunities for drug development. Expert Opin Ther Targets. 2016; 20(12):1463-1475. https://doi.org/10.1080/14728222.2016.1251582

44. Kim BS, Breuer B, Arnke K, Ruhl T, Hofer T, Simons D, et al. The effect of the macrophage migration inhibitory factor (MIF) on excisional wound healing in vivo. J Plast Surg Hand Surg. 2020; 54(3):137-144. https://doi.org/10.1080/2000656X.2019.1710710

45. Tessa M. Simone and Paul J. Higgins Inhibition of SERPINE1 Function Attenuates Wound Closure in Response to Tissue Injury: A Role for PAl-1 in Re-Epithelialization and Granulation Tissue Formation. J Dev Biol. 2015; 3:11-24. https://doi.org/10.3390/jdb3010011

46. Rui Guo, Linlin Chai, Liang Chen, Wenguang Chen, Liangpeng Ge, Xiaoge Li, et al. Stromal cell-derived factor 1 (SDF-1) accelerated skin wound healing by promoting the migration and proliferation of epidermal stem cells. In Vitro Cell Dev Biol Anim. 2015; 51(6):578-85. https://doi.org/10.1007/s11626-014-9862-y

47. Murphy JM, Young IG. IL-3, IL-5, and GM-CSF signaling: crystal structure of the human beta-common receptor Vitam Horm Journal. 2006. 74:1-30. https://doi. org/10.1016/S0083-6729(06)74001-8

48. Djuretic I, Gleason J, Guo Xinjian, Kaplunovsky A. Decellularized and dehydrated human amniotic membrane (DDHAM) in wound management: modulation of macrophage differentiation and activation. Wound Repair Regen. 2015; 23(2):A19-A19.

49. Ahuja N, Jin R, Powers C. Billi A, Bass K. Dehydrated Human Amnion Chorion Membrane as Treatment for Pediatric Burns. Advances in wound care. 2020; 9(11):602-612. https://doi.org/10.1089/wound.2019.0983

50. Fenelon M, Maurel DB, Siadous $R$, Gremare A, Delmond S, Durand $M$, et al. Comparison of the impact of preservation methods on amniotic membrane properties for tissue engineering applications. Mater Sci Eng. 2019, 104:109903. https://doi.org/10.1016/j.msec.2019.109903

51. Peter Alexander von Harbach Ferenczy, Luciene Barbosa de Souza. Comparison of the preparation and preservation techniques of amniotic membrane used in the treatment of ocular surface diseases. Rev Bras Oftalmol. 2020; 79(1):71-80. https://doi.org/10.5935/0034-7280.20200016

52. Gibbons G. W. Grafi ${ }^{\oplus}$, a Cryopreserved Placental Membrane, for the Treatment of Chronic/Stalled Wounds. Adv Wound Care (New Rochelle). 2015; 4(9):534-544. https://doi.org/10.1089/wound.2015.0647

53. Thomasen H, Pauklin M, Steuhl KP, Meller D. Comparison of cryopreserved and air-dried human amniotic membrane for ophthalmologic applications. Graefe's Arch Clin Exp. Ophthalmol. 2009; 247:1691-1700. https://doi.org/10.1007/s00417-009-1162-y

54. Rodríguez-Ares MT, López-Valladares MJ, Touriño R, Vieites B, Gude F, Silva MT, et al. Effects of lyophilization on human amniotic membrane. Acta Ophthalmol. 2009; 87:396-403. https://doi.org/10.1111/j.1755-3768.2008.01261.x

55. Niknejad H, Deihim $T$, Solati-Hashjin $M$, Peirovi $H$. The effects of preservation procedures on amniotic membrane's ability to serve as a substrate for cultivation of endothelial cells. Cryobiology. 2011; 63:145-151. https://doi.org/10.1016/j.cryobiol.2011.08.003

56. Chuck RS, Graff JM, Bryant MR, Sweet PM. Biomechanical Characterization of Human Amniotic Membrane Preparations for Ocular Surface Reconstruction. Ophthalmic Res. 2004; 36:341-348. https://doi.org/10.1159/000081637

57. Malhotra C, Jain AK. Human amniotic membrane transplantation: Different modalities of its use in ophthalmology. World J Transplant. 2014; 4:111-121. https:// doi.org/10.5500/wjt.v4.i2.111

58. Wilshaw SP, Kearney JN, Fisher J, Ingham E. Production of an acellular amniotic membrane matrix for use in tissue engineering. Tissue Eng. 2006, 12, 2117-2129. https://doi.org/10.1089/ten.2006.12.2117

59. Shablyy VA, Kuchma MD, Kyryk VM, Onishchenko GM, Tsupykov OM, Klymenko PP, et al. Phenotype and migration potential of multipotent mesenchymal stromal cells from native and cryopreserved human placenta. Biotechnologia acta. 2012; 5(5):59.

60. Lavery $L A$, Fulmer J, Shebetka KA, Regulski M, Vayser D, Fried D. The efficacy and safety of Grafix( $(\circledR)$ for the treatment of chronic diabetic foot ulcers: results of a multi-centre, controlled, randomised, blinded, clinical trial. Grafix Diabetic Foot Ulcer Study Group. Int Wound J. 2014; 11(5):554-60. https://doi.org/10.1111/ iwj. 12329

61. Available from: https://zakon.rada.gov.ua/laws/show/z0869-14\#n20

62. Shablii VA, Kuchma MD, Kyryk VM, Onishchenko AN, Lukash LL, Lobintseva GS. Cryopreservation human placental tissue as source of hematopoietic and mesenchymal stem cells. Cellular Transplantation \& Tissue Engineering. 2012; 7(1).

63. Shablii V, Kuchma M, Kyryk V, Onishchenko G, Tsupykov O, Klymenko $P$, et al. Characteristics of multipotent mesenchymal stromal stem cells derived from native and cryopreserved human placental tissue. Problems of Cryobiology and Cryomedicine. 2012; 22(2):157-160.

64. Walkden A. Amniotic Membrane Transplantation in Ophthalmology: An Updated Perspective. Clinical Ophthalmology. 2020;14:2057-2072. https://doi.org/10.2147/ OPTH.S208008

65. Zelen CM, et al. A prospective randomised comparative parallel study of amniotic membrane wound graft in the management of diabetic foot ulcers. Int Wound J. 2013; 10(5):502-7. https://doi.org/10.1111/iwj.12097 
66. Zelen CM, Gould L, Serena TE, et al. A prospective, randomised, controlled, multi-centre comparative effectiveness study of healing using dehydrated human amnion/corion membrane allograft, bioengineered skin substitute or standard of care for treatment of chronic lower extremity diabetic ulcers. Int Wound J. 2015; 12(6):724-32. https://doi.org/10.1111/iwj.12395

67. Zelen CM, Serena TE, Snyder RJ. A prospective, randomised comparative study of weekly versus biweekly application of dehydrated human amnion/chorion membrane allograft in the management of diabetic foot ulcers. Int Wound J. 2014; 11(2):122-8. https://doi.org/10.1111/iwj.12242

68. DiDomenic $L A$, Orgill $D P$, Galiano $R D$, et al. Aseptically processed placental membrane improves healing of diabetic foot ulcerations: prospective, randomized clinical trial. Plast Reconstr Surg Glob Open. 2016; 4(10):e1095. https://doi.org/10.1097/G0X.0000000000001095

69. Snyder RJ, Shimozaki K, Tallis A, et al. A prospective, randomized, multicenter, controlled evaluation of the use of dehydrated amniotic membrane allograft compared to standard of care for the closure of chronic diabetic foot ulcer. Wounds. 2016; 28(3):70-7.

70. Abdo RJ. Treatment of diabetic foot ulcers with dehydrated amniotic membrane allograft: a prospective case series. J Wound Care. 2016; 25(7):S4-9. https://doi. org/10.12968/jowc.2016.25.7.S4

71. Raphael A. A single-centre, retrospective study of cryopreserved umbilical cord/amniotic membrane tissue for the treatment of diabetic foot ulcers. J Wound Care. 2016; 25(7):S10-7. https://doi.org/10.12968/jowc.2016.25.7.S10

72. Tettelbach $W$, et al. A confirmatory study on the efficacy of dehydrated human amnion/chorion membrane dHACM allograft in the management of diabetic foot ulcers: a prospective, multicentre, randomised, controlled study of 110 patients from 14 wound clinics. Int Wound J. 2019; 16(1):19-29. https://doi.org/10.1111/ iwj. 12976

73. Kirsner RS, Sabolinski ML, Parsons NB, Skornicki M, Marston WA. Comparative effectiveness of a bioengineered living cellular construct vs a dehydrated human amniotic membrane allograft for the treatment of diabetic foot ulcers in a real world setting. Wound Repair Regen. 2015; 23(5):737-44. https://doi.org/10.1111/ wrr.12332

74. Koob TJ, Lim JJ, Zabek N, Massee M. Cytokines in single layer amnion allografts compared to multilayer amnion/chorion allografts for wound healing. J Biomed Mater Res B Appl Biomater. 2015; 103(5):1133-404. https://doi.org/10.1002/jbm.b.33265

75. Koizumi NJ, Inatomi TJ, Sotozono CJ, et al. Growth factor mRNA and protein in preserved human amniotic membrane. Curr Eye Res. 2000; 20:173-177. https:// doi.org/10.1076/0271-3683(200003)2031-9FT173

76. Miao Z, Jin J, Chen L, et al. Isolation of mesenchymal stem cells from human placenta: Comparison with human bone marrow mesenchymal stem cells. Cell Biol Int. 2006; 30:681-687. https://doi.org/10.1016/j.cellbi.2006.03.009

77. Maxson S, Lopez EA, Yoo D, Danilkovitch-Miagkova A, Leroux MA. Concise review: role of mesenchymal stem cells in wound repair. Stem Cells Transl Med. 2012; 1:142-14. https://doi.org/10.5966/sctm.2011-0018

78. Shin L, Peterson DA. Human mesenchymal stem cell grafts enhance normal and impaired wound healing by recruiting existing endogenous tissue stem/progenitor cells. Stem Cells Transl Med. 2013; 2:33-42. https://doi.org/10.5966/sctm.2012-0041

79. Makrantonaki E, Wlaschek M, Scharffetter-Kochanek K. Pathogenesis of wound healing disorders in the elderly. JDDG. 2017; 15(3):255-275. Available from: https://doi.org/10.1111/ddg.13199

80. Niknejad H, Peirovi H, Jorjani M, et al. Properties of the amniotic membrane for potential use in tissue engineering. Eur Cell Mater. 2008; 15:88-99. https://doi. org/10.22203/eCM.v015a07

81. Lakmal K, Basnayake O, Hettiarachchi D. Systematic review on the rational use of amniotic membrane allografts in diabetic foot ulcer treatment. BMC Surg. 2021; 21:87. https://doi.org/10.1186/s12893-021-01084-8

82. Brantley J, Verla T. Use of Placental Membranes for the Treatment of Chronic Diabetic Foot Ulcers. Adv Wound Care. 2015; 4(9). https://doi.org/10.1089/ wound.2015.0634

83. Au AS, Leung WY, Stavosky JW. Efficacy of Dehydrated Human Amnion Chorion Membrane in the Treatment of Diabetic Foot Ulcers. J Am Podiatr Med Assoc. 2021; 111(2). https://doi.org/10.7547/17-154

84. Glat $P$, Orgill $D$, Galiano $R$, et al. Placental Membrane Provides Improved Healing Efficacy and Lower Cost Versus a Tissue-Engineered Human Skin in the Treatment of Diabetic Foot Ulcerations. PRS Glob Open. 2019; 7:e2371. https://doi.org/10.1097/GOX.0000000000002371

85. Available from: https://www.wellrx.com/prescriptions/epifix\%20amniotic\%20membrane

86. Skin Substitutes for Treating Chronic Wounds. Technical Brief Project ID: WNDT0818, 2020. https://www.cms.gov/Medicare/Coverage/DeterminationProcess/ downloads/id109TA.pdf

87. Boboridis KG, Mikropoulos DG, Georgiadis NS. Hypopyon after Primary Cryopreserved Amniotic Membrane Transplantation for Sterile Corneal Ulceration: A Case Report and Review of the Literature. Case Rep Ophthalmol Med. 2021; 2021: 9982354. https://doi.org/10.1155/2021/9982354

88. Kubo M, Sonoda Y, Muramatsu R, Usui M. Immunogenicity of human amniotic membrane in experimental xenotransplantation. Invest Ophthalmol Vis Sci. 2001; 42:1539-1546.

89. Risman BV, Ivanov GG, Mustakimov DN. The treatment results of patients with purulent-necrotic complications of diabetic foot syndrome by using of modern wound coverings based on alginates, hydrocolloids and hydrogels (Wound coverings and diabetic foot syndrome). Wounds and Wound Infections. The Prof. B. M. Kostyuchenok Journal. 2017; 4(2):18-23. [In Russian]. https://doi.org/10.17650/2408-9613-2017-4-2-18-23

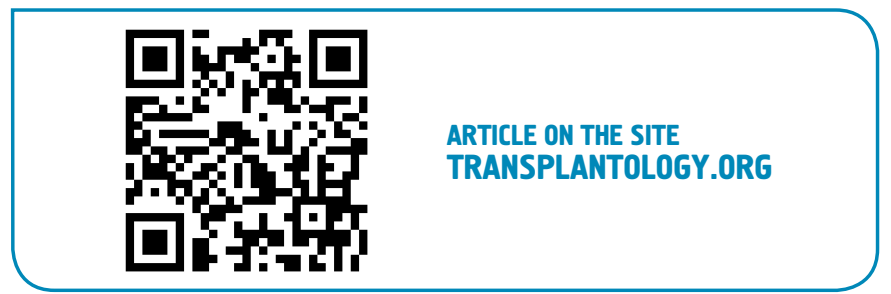




\title{
Клінічна ефективність застосування кріоконсервованої амніотичної мембрани людини при синдромі діабетичної стопи
}

\author{
Устименко А. М. ${ }^{1,2}$, Немтінов П. І., ${ }^{3,4}$, Болгарська С. В. ${ }^{5}$ Заіка Л. В. ${ }^{5}$, Шаблій В. А. ${ }^{4,6}$, \\ Букреєва Т. В. ${ }^{4}$ Орленко В. Л. ${ }^{5}$, Паляниця С. С. ${ }^{3}$ \\ ${ }^{1}$ ДУ «Інститут генетичної та регенеративної медицини НАМН Украӥни», Київ, Україна \\ ${ }^{2}$ ДУ «Інститут геронтології ім. Д. Ф. Чеботарьова НАМН України», Київ, Україна \\ ${ }^{3}$ Координаційний центр трансплантації органів, тканин $і$ клітин, Київ, Україна \\ ${ }^{4}$ ТОВ «Інститут клітинної терапії», Київ, Україна \\ ${ }_{5}^{5}$ ДУ «Інститут ендокринології та обміну речовин ім. В. П. Комісаренка НАМН Украйни», Київ, Украйна \\ ${ }^{6}$ Інститут молекулярної біології і генетики НАН України, Київ, Україна
}

\section{PE3ЮOME}

Синдром діабетичної стопи з тривало незагоюваними ранами - найбільш розповсюджене ускладнення та причина ампутації кінцівок при цукровому діабеті. Пошук ефективних терапевтичних засобів і включення їх до протоколів лікування є пріоритетним напрямком у зв'язку зі значним збільшенням щороку випадків цього соціально значущого захворювання та інвалідизації серед працездатного населення

МЕТА ДОСЛІДЖЕНнЯ: оцінити ефективність застосування кріоконсервованої амніотичної мембрани людини в лікуванні тривало незагоюваних ран нижніх кінцівок при синдромі діабетичної стопи.

MATEPIAЛИ ТА МЕTОДИ: В рамках клінічного дослідження описано 4 клінічні випадки лікування пацієнтів з цукровим діабетом I та II типів (1 жінка і 3 чоловіки у віці від 52 до 68 років) із тривало незагоюваними ранами нижніх кінцівок за умов стандартної терапії, яким після попередньої санації ран проводили аплікації препарату кріоконсервованої амніотичної мембрани людини. Раз на тиждень після аплікації ПКАМЛ на рану стопи оцінювали динаміку загоєння рани. Визначали рівень глюкози у крові до аплікації ПКАМЛ та через дві години після процедури.

РЕЗУЛЬТАТИ. При щотижневих застосуваннях ПКАМЛ відбувалось поступове зменшення площі рани від вихідного розміру та збільшення швидкості загоєння. Так, на момент другого візиту (через 7 днів) зменшення площі виразки від вихідного розміру у пацієнта 1 складало 33 \%, у пацієнта 2 - 25 \%, у пацієнта 3 - 33 \% на підошві і у пацієнта 4 - 3 \%, а швидкість загоєння виразки - 4,7 \%, 3,6 \%, 4,7 \% і 0,43 \% за добу відповідно. Застосування ПКАМЛ не впливало на рівень глюкози в крові при порівнянні значень до аплікації і через дві години після процедури. Чергові контрольні візити пацієнтів через 3, 6, 9 та 12 місяців від початку дослідження показали відсутність рецидивів виразок.

Висновки. Показано, що при застосуванні кріоконсервованої амніотичної мембрани людини у пацієнтів з цукровим діабетом та синдромом діабетичної стопи з тривало незагоюваними ранами відбувається повне загоєння виразок зі стійкою ремісією упродовж року спостереження.

кЛючовІ СлОвА: цукровий діабет; діабетична стопа; кріоконсервована амніотична мембрана людини; тканинна терапія 